\section{Good Corporate Governance dan Market Capitalization Dengan Variabel Moderating Corporate Social Responsibility Disclousure (Studi Kasus Pada Perusahaan Manufaktur Yang Terdaftar Di BEI)}

\author{
Kiswanto \\ Jurusan Akuntansi Fakultas Ekonomi Universitas Negeri Semarang \\ Kampus Sekaran, Gedung C6 It 3 Gunungpati, Semarang 52099 \\ Email: antok_bs@yahoo.com
}

\begin{abstract}
The purpose of this study is to test the effect of Good Corporate Governance (GCG) to the market Capitalization that is moderated by Corporate Social Responsibility (CSR). Using ordinary least squares approach (OLS) then the hypothesis would be tested in this study.

The results show that good corporate governance affect market capitalization. This means that the enterprise value will increase if the company increases the management company as well. CSR as a moderating variable also showed the influence of corporate governance on firm value through CSR. Although the results showed a significant effect between GCG to market capitalization through CSR as a moderation variable, but this study also has limitations. Among them are companies that are just a sample of manufacturing firms listed on the Indonesia Stock Exchange, and then only companies that submit annual reports over the web IDX (www.idx.co.id). Finally, future research is suggested not only using annual report companies that submit reports via the web. Since the company's annual report is very much related to the disclosure of information social responsibility (CSR).
\end{abstract}

Key Word : good corporate governance, social corporate responsibility disclousure, market capitalization

\title{
PENDAHULUAN
}

Monks \& Minow (2001) dalam Wardhani (2006) mengungkapkan bahwa Good Corporate Governance (GCG) merupakan tata kelola perusahaan yang menjelaskan hubungan antara berbagai partisipan dalam perusahaan yang menentukan arah dan kinerja perusahaan. Isu mengenai CG ini mulai mengemuka, khususnya di Indonesia, setelah Indonesia mengalami masa krisis yang berkepanjangan sejak tahun 1998. Banyak pihak yang mengatakan lamanya proses perbaikan di Indonesia disebabkan oleh sangat lemahnya CG yang diterapkan dalam perusahaan di Indonesia. Sejak saat itu, baik pemerintah maupun investor mulai memberikan perhatian yang cukup signifikan dalam praktek CG.

selain itu masih ada berbagai macam pertimbangan yang dilakukan oleh para investor dalam rangka menanamkan modalnya, salah satunya adalah kinerja tanggung jawab sosial. Dimana baru-baru ini kinerja tanggung jawab sosial (CSR) menjadi perbincangan yang sangat menarik dikalangan investor. Apalagi dengan diterbitkannya Undang-undang Perseroan terbatas No. 40 tahun 2007 yang mengatur tentang pentingya perusahaan bertanggungjawab terhadap masalah-

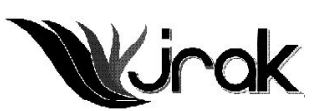

Jurnal Reviu Akuntansi dan Keuangan

ISSN: 2088-0685 Vol.1 No. 2, Oktober 2011 
Good

Corporate

Governance....

98 masalah sosial dan lingkungan. Penelitian Basamalah dan Jermias (2005) menunjukkan bahwa salah satu alasan manajemen melakukan pelaporan sosial adalah untuk alasan strategis.

Banyak penelitian yang telah mengkaji tentang pengaruh CSR terhadap nilai perusahaan maupun GCG terhadap nilai perusahaan. Namun banyak penelitian menemukan hasil yang tidak konsisten. Di Indonesia penelitian Suratno et al. (2006) memperoleh hasil bahwa kinerja lingkungan (CSR) berpengaruh positif terhadap kinerja ekonomi. Dimana hasil tersebut konsisten dengan Siegel dan Paul (2006) yang mengungkapkan bahwa CSR berpengaruh pada efisiensi, perubahan teknikal, dan skala ekonomi perusahaan. Hasil berbeda ditunjukkan oleh penelitian yang dilakukan Spicer (1978) menemukan adanya asosiasi antara nilai investasi saham dengan kinerja sosial perusahaan tetapi selalu menurun dari tahun pertama ke tahun berikutnya. Sedangkan penelitian Alexander dan Buchloz (1978) malah justru tidak menemukan adanya pengaruh antara pengungkapan sosial dengan harga saham sebagai wujud dari kinerja perusahaan.

Sesuai dengan arah tujuan penelitian ini maka dasar teori yang digunakan Stakeholder theory dan legitimacy theory, karena Stakeholder theory dan legitimacy theory merupakan teori yang paling tepat untuk mendasari penelitian di bidang tanggung jawab sosial perusahaan. Menurut Deegan (2004), teori stakeholder erat kaitannya dengan teori legitimacy. Keduanya menjelaskan alasan pengungkapan suatu informasi oleh perusahaan dalam laporan keuangan.

Freeman (1984) menyatakan bahwa stakeholder adalah: "any identifiable group or individual who can affect the achievement of an organisation's objectives, or is affected by the achievement of an organisation's objectives". Teori ini menyatakan bahwa seluruh stakeholder memiliki hak untuk disediakan informasi tentang bagaimana aktivitas organisasi dapat mempengaruhi arah tujuan mereka (sebagai contoh, melalui polusi, sponsorship, inisiatif pengamanan, dan lain-lain), bahkan ketika mereka memilih untuk tidak menggunakan informasi tersebut dan bahkan ketika mereka tidak dapat secara langsung memainkan peran yang konstruktif dalam kelangsungan hidup organisasi (Deegan, 2004).

Tujuan utama dari teori stakeholder adalah untuk membantu manajer korporasi mengerti lingkungan stakeholder mereka dan melakukan pengelolaan dengan lebih efektif di antara keberadaan hubungan-hubungan di lingkungan perusahaan mereka. Namun demikian, tujuan yang lebih luas dari teori stakeholder adalah untuk menolong manajer korporasi dalam meningkatkan nilai dari dampak aktifitas-aktifitas mereka, dan meminimalkan kerugian-kerugian bagi stakeholder. Pada kenyataannya, inti keseluruhan teori stakeholder terletak pada apa yang akan terjadi ketika korporasi dan stakeholder menjalankan hubungan mereka.

Disisi lain teori legitimacy menegaskan bahwa perusahaan terus berupaya untuk memastikan bahwa mereka beroperasi dalam bingkai dan norma yang ada dalam masyarakat atau lingkungan di mana perusahaan berada, mereka berusaha untuk memastikan bahwa aktifitas perusahaan dapat diterima oleh pihak luar sebagai sesuatu yang "sah" (Deegan: 2004).

Dalam pandangan teori legitimacy, perusahaan harus secara kontinyu beroperasi sejalan dengan nilai-nilai masyarakat. Hal ini seringkali dicapai melalui laporan perusahaan bentuk medium (Guthrie et al., 2006). Lindblom (1994) menyarankan bahwa perusahaan dapat menggunakan disclosure untuk memperlihatkan perhatian manajemen terhadap nilai-nilai masyarakat, atau untuk mengalihkan perhatian masyarakat dari pangaruh negatif dari aktifitas perusahaan.

Pentingya pengungkapan tanggungjawab social (CSR) terhadap peningkatan nilai perusahaan dan hasil penelitian yang masih tidak saling konsisten maka penelitian ini akan memberikan bukti empiris apakah Corporate Social Responsibility Disclousure berpengaruh terhadap nilai perusahaan dengan variabel moderasi Good Corporate Governance, karena dengan pentingnya pengungkapan tanggungjawab sosial menuntut perusahaan akan meningkatkan perbaikan mekanisme GCG perusahaan sehingga akan meningkatkan nilai perusahaan. 
Penelitian ini dilakukan terhadap perusahaan-perusahaan dalam kelompok industri manufaktur yang terdaftar di Bursa Efek Indonesia pada tahun 20062008. Pemilihan sampel penelitian didasarkan pada metode nonprobability sampling tepatnya metode purposive sampling. Adapun kriteria yang digunakan untuk memilih sampel pada penelitian ini adalah sebagai berikut:

1) Perusahaan sampel terdaftar di Bursa Efek Jakarta tahun 2006-2008 dalam kelompok industri manufaktur yang menerbitkan laporan tahunan (annual report) serta disajikan di web BEI secara berturut-turut

2) Perusahaan sampel mempunyai laporan keuangan yang berakhir 31 Desember dan menggunakan rupiah sebagai mata uang pelaporan.

3) Perusahaan sampel melakukan pengungkapan CSR dalam laporan tahunan secara berturut-turut selama tahun 2006-2008.

4) Perusahaan sampel memiliki semua data yang diperlukan secara lengkap.

Pengukuran variable penelitian ini dilakukan sebagai berikut:

a. Variabel Dependen

Variabel dependen, yaitu nilai perusahaan yang diukur dengan Tobin's Q. Tobin's $\mathrm{Q}$ dihitung dengan rumus:

\section{$\{($ CP x Jumlah Saham $)+$ TL + I $)\}-$ CA}

TA

Keterangan:

$\mathrm{CP}=$ Closing Price

$\mathrm{TL}=$ Total Liabilities

$\mathrm{I}=$ Inventory

$\mathrm{CA}=$ CurrentAssets

$\mathrm{TA}=$ TotalAssets

b. Variabel independen

Variabel independen penelitian ini adalah Good Corporate Governance. Corporate governance didefinisikan sebagai suatu sistem yang mengatur dan mengendalikan perusahaan untuk menciptakan nilai tambah (value added) untuk semua stakeholder-nya. Dalam penelitian ini digunakan 2 proxy untuk praktek corporate governance yaitu : pertama, Proporsi Dewan Komisaris Independen merupakan anggota dewan komisaris yang tidak terafiliasi dengan manajemen, anggota dewan komisaris lainnya dan pemegang saham pengendali, serta bebas dari hubungan bisnis atau hubungan lainnya yang dapat mempengaruhi kemampuannya untuk bertindak independen atau bertindak semata-mata demi kepentingan perusahaan (Komite Nasional Kebijakan Governance, 2004). Kedua, Keberadaan Komite Audit, dimana variabel ini diukur berdasarkan jumlah anggota Komite Audit pada perusahaan yang menjadi sampel pada penelitian ini (Veronica, 2005).

c. Variabel Moderating

Variabel Moderasi dalam penelitian ini adalah Corporate Social Responsibility (pengungkapan tanggung jawab sosial). Pengungkapan tanggung jawab sosial merupakan data yang diungkapkan oleh perusahaan berkaitan dengan aktivitas sosialnya meliputi kategori: Lingkungan, Energi, Sumberdaya Manusia, Produk dan Pelanggan, Keterlibatan Komunitas/Masyarakat, dan Umum.

Kategori jumlah pengungkapan informasi tanggung jawab sosial dimodifikasi dari penelitian Branco \& Rodrigues (2006): 
Good

Corporate

Governance....

100

Gambar 1

Model Pengujian

dengan Amos untuk

$\mathrm{H} 1$ dan $\mathrm{H} 2$ a) Lingkungan (Environment);

b) Energi (Energy)

c) Sumberdaya Manusia (Human Resources);

d) Produk dan Pelanggan (Products and Consumers);

e) Keterlibatan Komunitas/Masyarakat (Community Involvement)

f) Umum (Others)

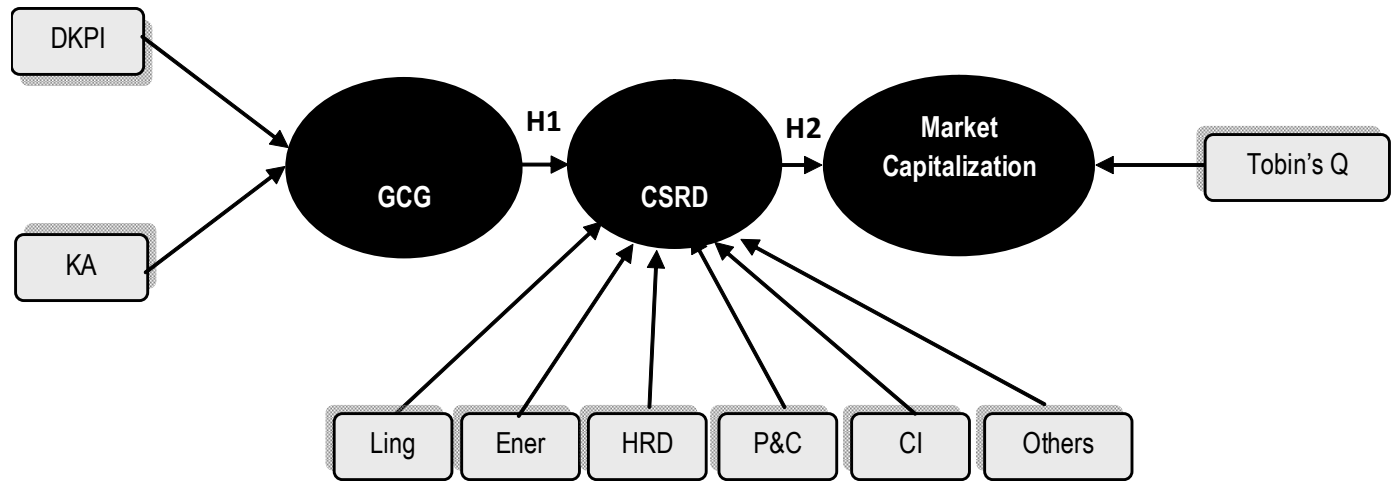

Keterangan :

$\begin{array}{llll}\text { DKPI } & =\text { Dewan Komisaris Independen } & \text { HRD } & =\text { Sumber Saya Manusia } \\ \text { KA } & =\text { Komite Audit } & \text { P \& C } & =\text { Produk dan Pelanggan } \\ \text { Ling } & =\text { Lingkungan } & \text { CI } & =\text { Keterlibatan Masyarakat } \\ \text { Ener } & =\text { Energy } & \text { Others } & =\text { Umum }\end{array}$

Total skor maksimum pengungkapan tanggung jawab sosial ini adalah 53. Skor maksimum untuk masing-masing kategori adalah 6 untuk Lingkungan, 3 untuk Energi, 25 untuk Sumberdaya Manusia, 7 untuk Produk dan Pelanggan, dan 10 untuk Keterlibatan Komunitas/Masyarakat, dan 2 untuk kategori Umum.

Analisis Data Moderasi pengungkapan CSR pada pengaruh GCG terhadap nilai perusahaan ini dilakukan dengan menggunakan SPSS for windows version 16.0 Selanjutnya hubungan antar variabel digambarkan pada diagram alur penelitian sebagai berikut:

Langkah selanjutnya adalah mengevaluasi Goodness of fit model penelitian ini dengan menggunakan nilai uji ANOVA. Dimana jika nilai signifikansinya di bawah 5\%, maka hal itu berarti bahwa model penelitian telah memenuhi asumsi Goodness of fit. Jika nilai Goodness of fit berada diatas 5\% maka model tersebut tidak layak untuk dilakukan analisis selanjutnya. Selanjutnya model penelitian yang akan diuji hipotesis terdiri dari :

$\mathrm{MC}$

: $\mathrm{b} 0+\mathrm{b} 1 \mathrm{GCG}+\mathrm{e}$

$\mathrm{MC}$

: $b 0+b 1(G C G \times$ CSRD $)+e$

Ket

$\mathrm{MC}$

: Market Capitalization (Tobin's Q model)

GCG

: Good Corporate Governance (yang terdiri dari 2 indikator yaitu Dewan Komisaris Independen dan jumlah Komite Audit)

CSRD

: Corporate Social Responsibility (terdiri dari enam Indikator)

GCG x CSRD : Perkalian antara Jumlah Skor indikator GCG dengan Jumlah Skor CSRD

Setelah model dinyatakan diterima dilihat dari hasil Goodness of fit, maka selanjutnya adalah analisis uji hipotesis, dimana criteria untuk menerima atau menolak hipotesis dalam penelitian ini berdasarkan nilai signifikansi adalah sebagai berikut:

a. jika nilai signifikansi $<0,05$, maka Ho ditolak dan Ha diterima, berarti variabel GCG berpengaruh signifikan terhadap kinerja perusahaan yang diukur 

market capitalization

b. Jika nilai signifikansi ${ }^{3}$ 0,05, maka Ho diterima dan Ha ditolak, berarti variabel GCG tidak berpengaruh signifikan terhadap kinerja perusahaan yang diukur dengan market capitalization. GCG yang diinterveningi oleh CSRD berpengaruh signifikan terhadap kinerja perusahaan yang diukur dengan marketcapitalization.

\section{HASIL DAN PEMBAHASAN}

Penelitian ini mengambil sampel perusahaan sektor manufaktur yang terdaftar di Bursa Efek Jakarta. Gambaran statistik masing-masing indikator variabel mengenai perusahaan sampel penelitian ini disajikan dalam tabel berikut:

\begin{tabular}{lcccc}
\hline \multicolumn{1}{c}{ Kategori } & Maxs & \multicolumn{2}{c}{ Laporan Tahunan } \\
Pengungkapan & Min & Max & 6 & Mean \\
\hline Lingkungan & 6 item & 3 & 3 & 4.46 \\
Energi & 3 item & 1 & 25 & 2.08 \\
Sumber Daya Manusia & 25 item & 11 & 7 & 18.08 \\
Produk dan Pelanggan & 7 item & 3 & 10 & 5.13 \\
Keterlibatan Komunitas & 10 item & 2 & 2 & 5.75 \\
Umum & 2 item & 2 & 2.00 \\
\hline
\end{tabular}

Tabel 1

Jumlah Informasi Corporate Social Resposibility Di Laporan Tahunan Masing-Masing Perusahaan 20062009

Sumber: Hasil Olah data 2010

Berdasarkan hasil olah data diketahui bahwa rata-rata paling banyak diungkapan pada informasi yang terkait dengan Pengungkapan Tanggungjawab Sosial (CSRD) adalah untuk indicator Sumber Daya Manusia. Dimana skor pengungkapan indikator Sumber daya manusia mencapai 11 item pengungkapan dari 25 nilai maksimal yang harus diungkapkan. Hal ini menjadi indikator bahwa perusahaan manufaktur yang menjadi sampel penelitian lebih cenderung untuk menggarap dan selalu meingkatkan kualitas sumber daya manusianya guna mendukung peningkatan kualitas perusahaan.

Selanjutnya adalah tentang komposisi Komite Audit dan Dewan Komisaris dimasing-masing perusahaan sampel. Disajikan sebagai berikut:

\begin{tabular}{lcc}
\hline & $\begin{array}{c}\text { Dewan Komisaris } \\
\text { Independen }\end{array}$ & Komite Audit \\
\hline $\mathrm{N}$ & 52 & 52 \\
Minimum & 0 & 0 \\
Maximum & 10 & 6 \\
Mean & 4 & 2 \\
Std. Deviation & 2,124 & 1,662 \\
Variance & 4,510 & 2,761 \\
\hline
\end{tabular}

Tabel 2

Jumlah Komposisi

Dewan Komisari Independen Dan

Komite Audit

Masing-Masing

Perusahaan 20062009

Rata-rata komposisi Dewan komisaris Independen pada perusahaan sampel adalah sebanyak 4 komisaris independen yang berasal dari luar perusahaan sehingga dimungkinkan dapat menjamin pengelolaan perussahaan secara lebih baik. Sedangkan komposisi komite audit dimasing-masing perusahaan rata-rata adalah 2 anggota komite audit, hal ini diharapkan dapat menjamin pengendalian intern sehingga dapat meningkatkan kualitas informasi yang akan disampaikan ke pihak eksternal yang pada akhirnya dapat meningkatkan kepercayaan pihak ketiga. Tetapi disisi lain masih ada perusahaan yang tidak memiliki dewan komisaris dan komite audit, sehingga hal ini tidak sesuai dengan peraturan BAPPEPAM dan UU PT. 


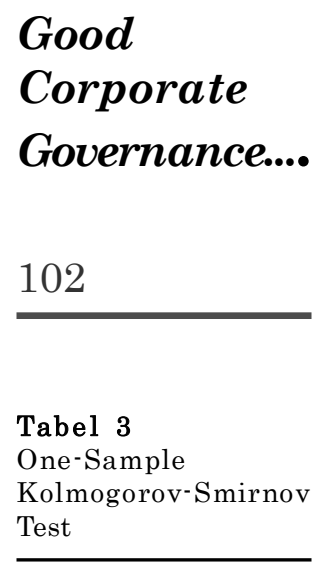

Tabel 4

Uji Autokorelasi

Tabel 5

Uji Multikolinearitas Dengan VIF
Hasil uji normalitas data disajikan sebagai berikut:

\begin{tabular}{llrrrr}
\hline & \multicolumn{1}{c}{$\begin{array}{c}\text { Market } \\
\text { Capitalization }\end{array}$} & CSRD & GCG & GCG x CSRD \\
\hline $\mathrm{N}$ & & 52 & 52 & 52 & 52 \\
Normal Parameters(a,b) & Mean & 648.28 & 37.50 & 6.06 & 229.13 \\
& Std. Deviation & 677.009 & 6.163 & 2.817 & 117.328 \\
Most Extreme Differences & Absolute & .224 & .198 & .203 & .107 \\
& Positive & .224 & .198 & .143 & .084 \\
& Negative & -.171 & -.148 & -.203 & -.107 \\
Kolmogorov-Smirnov Z & & 1.612 & 1.431 & 1.467 & .769 \\
Asymp. Sig. (2-tailed) & & .110 & .333 & .271 & .596 \\
\hline
\end{tabular}

Sumber : Hasil Olah Data, 2010

Hasil pengujian normalitas tersebut diatas, yaitu antara variable Market Capitalization (kinerja Perusahaan), CSRD dan GCG menunjukkan bahwa data ternyata berdistribusi normal. Hal itu dibuktikan dengan nilai signifikansi sesuai dengan kriteria yang ditentukan sebesar $>0,05$, dimana nilai signifikansi variabel Market Capitalization sebesar 0,110>0,05, CSRD sebesar 0,333, dan GCG sebesar 0,271 . Dengan demikian dapat disimpulkan bahwa pada pengujian normalitas tersebut diatas dikatakan berdistribusi normal, sehingga dapat dilakukan ke pengujian selanjutnya.

Selanjutnya adalah uji Autokorelasi yang digunakan untuk mengetahui ada tidaknya hubungan data antar tahun selama periode penelitian. Uji autokorelasi dalam penelitian ini menggunakan Koefisien Durbin Watson. Hasil perhitungan dengan SPSS versi 16.0 memberikan hasil nilai koefisien Durbin-Watson sebesar 1,856 .

\begin{tabular}{lc}
\hline Model & Durbin-Watson \\
\hline 1 (GCG to MC) & 1,345 \\
2 (GCG $\times$ CSRD to MC) & 1,481 \\
\hline
\end{tabular}

Sumber: Data sekunder diolah, 2010

Suatu model tidak mengalami gejala Autokorelasi jika nilai Koefisien DurbinWatson terletak antara dU dan 4 - dU. Adapun nilai dU untuk $\mathrm{N}=52$ dan jumlah variabel bebas sebanyak 2 pada taraf signifikansi sebesar 0,05 adalah sebesar 1,778. Sehingga nilai $4-\mathrm{dU}=4-1,778=2,222$. Dengan demikian dari tabel tersebut di atas diperoleh nilai Durbin-Watson adalah sebesar 1,345 dan 1,481 dimana terletak antara 1,778 - 2,222 atau dU < DW ( (4-dU). Karena nilai Koefisien Durbin-Watson terletak antara dU dan 4 - dU maka dikatakan bahwa tidak terjadi autokorelasi antara variabel-variabel dalam penelitian ini.

Uji multikolinearitas dalam penelitian ini menggunakan koefisien VIF. Dimana suatu penelitian dapat dikatakan terhindar dari gejala multikolonearitas jika nilai koefisien VIF dibawah 10. Hasil perhitungan dengan SPSS memberikan hasil seperti yang tampak pada tabel 5 , sebagai berikut:

\begin{tabular}{|c|c|c|}
\hline \multirow{2}{*}{ Variabel } & \multicolumn{2}{|c|}{ Collinearity Statistics } \\
\hline & Tolerance & VIF \\
\hline GCG & 0,998 & 1,002 \\
\hline GCG X CSRD & 0,997 & 1,003 \\
\hline
\end{tabular}

Sumber: Hasil olah data, 2010

Hasil pengujian multikolinieritas denga melihat nilai VIF menujukkan bahwa nilai VIF di bawah 10 sehingga dikatakan tidak terjadi multikolinearitas dalam penelitian ini. Dengan demikian terpenuhinya asumsi-asumsi yang diperlukan 
dalam analisis regresi linear (asumsi klasik), maka model penelitian dapat dianalisis dengan menggunakan analisis regresi linear berganda.

Uji goodness of fit model dilakukan sebelum melakukan pengujian penelitian ini terdiri dari du tahap pengujian, yaitu tahap pertama adalah menguji pengaruh good corporate governance terhadap market capitalization. Dan yang kedua adalah menguji good corporate governance terhadap market capitalization dengan variable mediasi CSRD. Hasil uji goodness of fit model dengan melihat nilai F (ANOVA) ditunjukkan dengan tabel sebagai berikut:

\begin{tabular}{lcc}
\hline \multicolumn{1}{c}{ Model } & F & Sig. \\
\hline 1 (GCG to MC) & 5,850 & 0,019 \\
2 (GCG x CSRD to MC) & 9,828 & 0,003 \\
\hline Sumber : Hasil Olah Data, 2010 & &
\end{tabular}

Uji menunjukkan goodness of fit model menunjukkan bahwa Model 1 GCG to $\mathrm{MC}$ mempunyai nilai $\mathrm{F}$ sebesar 5,850 dengan nilai sig. 0,019 dan mode 2 interaksi GCG X CSRD to MC mempunyai nilai F sebesar 9,828 dengan nilai sig. 0,003. Hasil ini menunjukkan bahwa model regresi tersebut dapat digunakan untuk memprediksi nilai Tobins'Q sebagai indicator pengukuran kinerja perusahaan, karena telah memenuhi kriteria goodness of fit model.

Berdasarkan hasil pengujian hipotesis pengaruh antara Good Corporate Governance berpengaruh terhadap Market Capitalization dan Corporate Social Respondibility Disclousure memoderasi pengaruh Good Corporate Governance terhadap Market Capitalization menunjukkan hasil sebagai berikut:

\begin{tabular}{lcccc}
\multicolumn{1}{c}{ Model } & T & Sig. & R Square & $\begin{array}{c}\text { Unstandardized } \\
\text { Coefficients }\end{array}$ \\
\hline 1 (GCG to MC) & 2,419 & 0,019 & 0,087 & 77,771 \\
2 (GCG x CSRD to MC) & 3,315 & 0,003 & 0,148 & 2,339 \\
\hline
\end{tabular}

Sumber : Hasil Olah Data, 2010

Pengujian Hipotesis 1 (Good Corporate Governance berpengaruh terhadap Market Capitalization)

Pengujian hipotesis 1 menunjukkan bahwa nilai t 2,419 dengan sig. 0,019 pada pengaruh Good Corporate Governance berpengaruh terhadap Market Capitalization. Yang berarti bahwa Hipotesis 1 diterima, dimana Good Corporate Governance berpengaruh dan signifikan terhadap Market Capitalization. Kuatnya pengaruh Good Corporate Governance terhadap Market Capitalization ditunjukkan dengan nilai R Square sebesar 0,087, yang berarti bahwa pengaruh Good Corporate Governance terhadap Market Capitalization adalah sebesar 8,7\% sedangkan pengaruh sisanya ditentukan oleh variable lain yang tidak masuk dalam model penelitian ini.

\section{Pengujian Hipotesis 2 (Corporate Social Respondibility Disclousure memediasi pengaruh Good Corporate Governance terhadap Market Capi- talization)}

Pengujian hipotesis 2 menunjukkan bahwa nilai t 3,315 dengan sig. 0,003 pada pengaruh Good Corporate Governance terhadap Market Capitalization yang dimediasi oleh Corporate Social Respondibility Disclousure. Yang berarti bahwa Hipotesis 2 diterima, dimana pengaruh Good Corporate Governance terhadap Market Capitalization yang dimediasi oleh Corporate Social Respondibility Disclousure. Kuatnya pengaruh Good Corporate Governance terhadap Market Capitalization yang dimediasi oleh Corporate Social Respondibility Disclousure ditunjukkan dengan nilai R Square sebesar 0,148, yang berarti bahwa pengaruh Corporate Social Respondibility Disclousure memediasi pengaruh Good Corporate Governance
JRAK

Tabel 6

Uji Goodness Of Fit Model

Tabel 7

Hasil Uji Hipotesis 


\section{Good}

Corporate

Governance....

104 terhadap Market Capitalization adalah sebesar 14,8\% sedangkan pengaruh sisanya ditentukan oleh variable lain yang tidak masuk dalam model penelitian ini.

Diterimanya hipotesis 1 (satu) menunjukkan bahwa Good Corporate Governance berpengaruh terhadap Market Capitalization. Hal ini sesuai dengan penelitian Klapper dan Love (2002), Black et al. (2003), Johnson et al. (2000), Silveira dan Barros (2006) yang menemukan bahwa GCG berpengaruh positif terhadap kinerja perusahaan dan nilai perusahaan bersangkutan. Rustiarini (2010) yang menunjukkan bahwa pengungkapan corporate governance berpengaruh pada nilai perusahaan.

Lebih lanjut Deegan (2004) menyatakan bahwa teori stakeholder menekankan akuntabilitas organisasi jauh melebihi kinerja keuangan atau ekonomi sederhana. Teori ini menyatakan bahwa organisasi akan memilih secara sukarela mengungkapkan informasi tentang kinerja lingkungan, sosial dan intelektual mereka, melebihi kewajibannya. Corporate governance yang merupakan konsep yang didasarkan pada teori keagenan, diharapkan bisa berfungsi sebagai alat untuk memberikan keyakinan kepada para investor bahwa mereka akan menerima return atas dana yang telah mereka investasikan. Corporate governance berkaitan dengan bagaimana para investor yakin bahwa manajer akan memberikan keuntungan bagi mereka, yakin bahwa manajer tidak akan mencuri/menggelapkan atau menginvestasikan ke dalam proyek-proyek yang tidak menguntungkan berkaitan dengan dana/kapital yang telah ditanamkan oleh investor, dan berkaitan dengan bagaimana para investor mengontrol para manajer (Shleifer dan Vishny, 1997). Dengan kata lain corporate governance diharapkan dapat berfungsi untuk menekan atau menurunkan biaya keagenan (agency cost).

Diterimanya hipotesis 2 (dua) menunjukkan bahwa Corporate Social Responsibility Disclousure memediasi pengaruh antara Good Corporate Governance terhadap Market Capitalization. Hal ini berarti bahwa corporate governance berpengaruh pada hubungan pengungkapan CSR dengan nilai perusahaan (Market Capitalization) atau Corporate Social Responsibility Disclousure memediasi pengaruh antara Good Corporate Governance terhadap Market Capitalization. Hal ini sesuai dengan penelitian Rustriarini (2010) menunjukkan bahwa salah satu tujuan pelaksanaan corporate governance adalah mendorong timbulnya tanggung jawab perusahaan pada masyarakat dan lingkungan.

Lebih lanjut Zhuang (2000) dalam Gunarsih (2003) meneliti corporate governance pada lima negara, Indonesia, Republik Korea, Malaysia, Philipina dan Thailand. Karakteristik corporate governance pada lima negara, sebagaimana pada banyak negara Asia Timur lainnya berdasarkan observasi yang dilakukan, adalah tidak efektifnya dewan direksi, lemahnya pengendalian internal, lemahnya audit, kurangnya disclosure yang mencukupi, kurangnya pelaksanaan legal, serta terkonsentrasinya kepemilikan perusahaan. Hal ini menunjukkan bahwa Corporate Social Responsibility Disclousure dapat meningkatkan pengaruh antara Good Corporate Governance terhadap Market Capitalization. Corporate governance merupakan variabel pemoderasi pada hubungan pengungkapan CSR dengan nilai perusahaan. Hasil penelitian ini menunjukkan bahwa salah satu tujuan pelaksanaan corporate governance adalah mendorong timbulnya tanggung jawab perusahaan pada masyarakat dan lingkungan. Kegiatan ini bertujuan untuk mengoptimalkan nilai perusahaan dengan tetap memperhatikan pemangku kepentingan lainnya. Penerapan corporate governance yang baik mendorong perusahaan melaksanakan aktivitas CSR sehingga dapat meningkatkan reputasi perusahaan.

\section{SIMPULAN}

Hasil ini memperkuat hasil penelitian Rustiarini (2010), Klapper dan Love (2002), Black et al. (2003), dan Silveira dan Barros (2006) yang menunjukkan bahwa Good Corporate Governance berpengaruh pada nilai perusahaan, namun menentang hasil penelitian Dahlia dan Siregar (2008), Nurlela dan Islahuddin (2008). Hasil penelitian ini memberikan arti bahwa para investor di Indonesia 
bersedia memberikan premium lebih kepada perusahaan yang memberikan transparansi atas pelaksanaan Good Corporate Governance dalam laporan tahunan mereka. Semakin tinggi tingkat transparansi perusahaan, maka semakin tinggi pula nilai perusahaan yang ditunjukkan dengan tingginya harga saham perusahaan.

Variabel Corporate Social Responsibility Disclousure sebagai variabel moderating pada pengaruh Good Corporate Governance dengan nilai perusahaan berpengaruh secara signifikan. Hal ini berarti penerapan Good Corporate Governance telah menuntun perusahaan untuk melaksanakan CSR dengan baik yang pada akhirnya akan berpengruh pada peningkatan nilai perusahaan. Indikator yang bisa diamati adalah dengan peningkatkan harga saham perusahaan sebagai respon positif ivestor atas pengelolaan perusahaan yang baik telah dilakukan oleh manajemen perusahaan.

Pengungkapan CSR merupakan salah satu keunggulan kompetitif bagi perusahaan sehingga diharapkan dapat meningkatkan kesadaran perusahaan untuk mengimplementasi dan mengungkapkan aktivitas CSR yang dilakukan. Selain itu, hasil penelitian ini diharapkan dapat memberikan kontribusi bagi pihak-pihak yang berkepentingan seperti pemerintah, Bapepam, dan IAI dalam merumuskan kebijakan, peraturan, dan standar terkait dengan tanggung jawab sosial perusahaan di Indonesia.

Penelitian ini memiliki keterbatasan-keterbatasan. Pertama, tidak semua perusahaan mencantumkan laporan tahunannya di web BEI, sehingga penulis kesulitan untuk mengakses data terkait dengan CSRD. Kedua, data CSR yang digunakan dalam penelitian ini sebagian besar berasal dari laporan tahunan perusahaan sehingga tidak semua item diungkapkan secara jelas. Item pengungkapan tanggung jawab sosial perusahaan yang digunakan penelitian ini juga masih mengacu pada instrumen yang digunakan oleh Sembiring pada tahun 2005. Berdasarkan keterbatasan di atas, maka penelitian selanjutnya diharapkan untuk menganalisis aktivitas CSR perusahaan secara lebih mendalam pada laporan tanggung jawab sosial terpisah serta memperbaharui item pengungkapan tanggung jawab sosial yang telah disesuaikan dengan kondisi masyarakat saat ini. Ketiga, adanya keterbatasan data tentang indeks corporate governance menyebabkan penelitian ini menggunakan proporsi komisaris independen, dan jumlah anggota komite audit sebagai proksi untuk mengukur praktek good corporate governance seperti yang telah banyak dilakukan penelitian saat ini (Veronica, 2005). Penelitian selanjutnya diharapkan untuk mengembangkan suatu instrumen pengukuran khusus untuk menghitung indeks Good Corporate Governance pada perusahaanperusahaan publik di Indonesia, serta memperbanyak sampel penelitian.

\section{DAFTAR PUSTAKA}

Alexander, John. J dan Buchloz. 1978. A Reason for Differences in Corporate Social Reporting. Critical Perspectives on Accounting. Vol. 10, p. 521-547

Bassamalah, Anies S., dan Johnny Jermias. 2005. "Social and Environmental Reporting and Auditing in Indonesia: Maintaining Organizational Legitimacy?" Gadjah Mada International Journal of Business. January-April Vol. 7 No. 1. pp: $109-127$

Black, Bernard S H. Jang, dan W Kim. 2003. Does Corporate Governance affect Firm Value? Evidence from Korea. Finance Working Paper No.103/2005, http:/ /papers.ssrn.com/sol3/papers.cfm?abstract_id=222491, tgl download 13 Mei 2007

Branco, Manuel Castelo dan Rodriugues, Lima Lucia. 2006. Communication of Corporate Responsibility by Portuguese Banks. A Legitimacy Theory Perspective. Corporate Communication: An International Journal Vol. 11 No.3. pp $232-248$

Dahlia, Lely, dan Sylvia Veronica Siregar. 2008. Pengaruh Corporate Social Responsibility Terhadap Kinerja Perusahaan. Simposium Nasional Akuntansi XI Pontianak 
Good

Corporate

Governance....

106
Deegan, C. 2004. Financial Accounting Theory. McGraw-Hill Book Company. Sydney

Freeman R.E.1984. Strategic Management: a Stakeholder Approach.Pitman.Boston

Gunarsih, Tri. 2003. Struktur Kepemilikan Sebagai Salah Satu Mekanisme Corporate Governance. Jurnal Kompak, Nomor 8

Guthrie, J., and L.D. Parker, and F. Ricceri. 2006. "The voluntary reporting of intellectual capital; comparing evidence from Hong Kong and Australia". Journal of Intellectual Capital. Vol. 7 No. 2. pp. 254-271

Johnson, Simon, P. Boone, A. Breach, dan E. Friedman. 2000. Corporate Governance in Asian Financial Crisis. Journal of Financial Economics, 58. pp 141186

Klapper, Leora dan Inessa Love. 2002. Corporate Governance, Investor Protection and Performance in Emerging Market. http://ssrn.com

Komite Nasional Kebijakan Governance, (2004). Pedoman Tentang Komisaris Independen. http://www.governance-indonesia.or.id/main.htm

Lindblom, C. K. (1994), "The Implications of Organizational Legitimacy for Corporate Social Performance and Disclosure", Critical Perspectives on Accounting Conference, New York

Nurlela, Rika dan Islahuddin. 2008. Pengaruh Corporate Social Responsibility Terhadap Nilai Perusahaan dengan Prosentase Kepemilikan Manajemen Sebagai Variabel Moderating, Simposium Nasional Akuntansi XI Pontianak

Rustriani, Ni Wayan. 2010. Pengaruh Corporate Governance pada Hubungan Corporate Social Resposibility dan Nilai Perusahaan. Makalah Disampaikan dalam Simposium Nasional Akuntansi ke-10. Makasar, 26 - 28 Juli

Sembiring, Edi Rismanda. 2005. "Karakteristik Perusahaan dan Pengungkapan Tanggung Jawab Sosial: Studi Empiris pada Perusahaan yang Tercatat di Bursa Efek Jakarta”. Makalah Disampaikan dalam Simposium Nasional Akuntansi VIII. Solo, 15 - 16 September

Shleifer, A., Vishny, R.W. 1997. A Survey of Corporate Governance. http:// www.ssrn.com

Siegel, Donald dan Paul, Chaterina J. 2006. Corporate Social Responsibility and Economic, Springer Science and Business Media, p. 207-211

Silveira, Alexandre di Micelli dan Lucas Ayres Barros. 2006. Corporate Governance Quality and Firm Value in Brazil. http: //papers.ssrn.com/sol3/papers

Spicer, Barry H. 1978. Investors, Corporate Social Performance and Information Disclosure The Accounting Review, Vol. 53, No. 1, January, pp. 94-111

Suratno, Ignatius Bondan, Darsono, dan Siti Mutmainah. 2006. "Pengaruh Environmental Performance terhadap Environmental Disclosure dan Economic Performance (Studi Empiris pada Perusahaan Manufaktur yang Terdaftar di Bursa Efek Jakarta periode 2001-2004)”. Makalah Disampaikan dalam Simposium Nasional Akuntansi Ke-9. Padang, 23 - 26 Agustus 2006

Undang-Undang Republik Indonesia Nomor 25 Tahun 2007 tentang Penanaman Modal. www.castleasia.com

Veronica, Sylvia dan Utama, Sidharta. 2005. Pengaruh Struktur Kepemilikan, Ukuran Perusahaan dan Praktek Corporate Governance Terhadap Pengelolaan Laba (Earnings Management). Simposium Nasional Akuntansi VIII: Solo

Wardhani, Ratna. 2006. Mekanisme Corporate Governance dalam Perusahaan yang Mengalami Permasalahan Keuangan (Financially Distressed Firms). SNA 9 Padang 